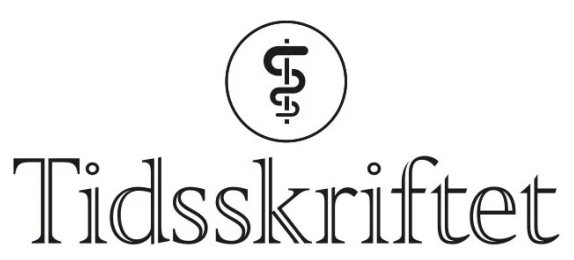

DEN NORSKE LEGEFORENING

\title{
Leif Jan Bjørnson
}

MINNEORD

ANETTE HYLEN RANHOFF

THOMAS SVENDSEN

NJAAL STRAY

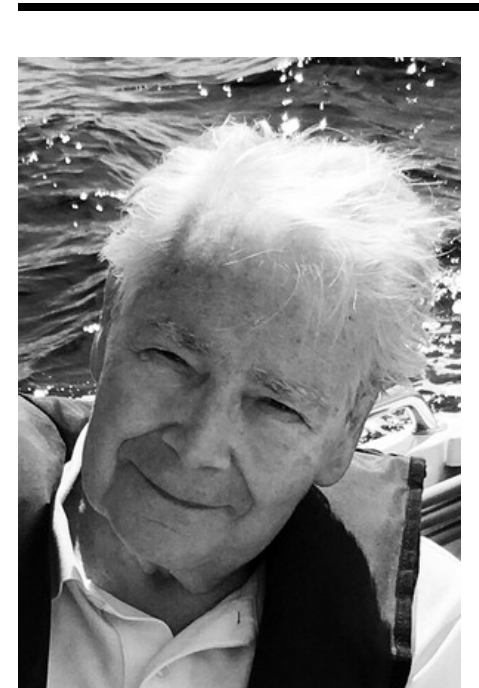

Så er han borte, vår læremester, kollega og venn. Leif Jan døde 16. desember, 82 år gammel, med sine kjæreste rundt seg i det hjemmet han var så glad i.

Leif Jan studerte medisin i Skottland, ble nyremedisiner og tok doktorgrad om blodplater. Så skjedde det et vendepunkt, og god og tverrfaglig behandling av eldre pasienter ble hans faglige livsoppgave. Han var en pioner innen utviklingen av geriatriske sykehustjenester og ledet en av landets første geriatriske avdelinger i Menighetssøsterhjemmet. Fra 1987 jobbet han på Diakonhjemmet Sykehus, hvor vi var hans kolleger.

Leif Jan var opptatt av det tverrfaglige samarbeidet mellom leger, sykepleiere og resten av det geriatriske teamet med fysioterapeut, ergoterapeut og sosionom. Ved deltakelse på fagkongresser tok han med seg hele behandlingsteamet.

Pårørendes betydning sto sentralt i hans tenkning, deriblant omsorgen for pårørende til personer med demens. Han var opptatt av ressursene i pasientens nettverk og utviklet systematiske nettverksmøter for å sikre pasienten best mulig støtte. 
Leif Jan var engasjert i utviklingen av metoder for vurdering av geriatriske pasienter og oppnådde internasjonal anerkjennelse. Kolleger fra inn- og utland ble ofte invitert til hans hjem, hvor det var god mat, musikk og sang. Han var aktiv i Norsk forening for geriatri og alltid en god ambassadør for faget. Hans ferdigheter som pedagog og taler var glimrende, og som pensjonist var han en ettertraktet foredragsholder.

Leif Jan var glad i mennesker. Han tok seg selv lite høytidelig, og det var alltid en god stemning omkring ham. Omsorgen for medarbeiderne var stor, og han deltok i både kor og dansegruppe på Diakonhjemmet. Vi vet at Leif Jan hadde stor glede av sitt arbeid innenfor frimurerlosjen, hvor han etter hvert fikk store oppgaver.

Da han som seksjonsoverlege ble pensjonist i 2005, etterlot han seg en moderne og veldrevet geriatriseksjon med akuttgeriatrisk sengepost og poliklinikk med tverrfaglige hjemmebesøk og daghospital for utredning blant annet av demens. Det har vært en glede for oss å fortsette dette arbeidet.

Vi takker for alt Leif jan har gjort for norsk geriatri, for Diakonhjemmet Sykehus, for kolleger og medarbeidere og for oss som venn.

Våre varmeste tanker og takk går til Elisabeth, barn og barnebarn, for at vi fikk en del av ham. Vi lyser fred over hans minne.

Publisert: 31. januar 2022. Tidsskr Nor Legeforen. DOI: 10.4045/tidsskr.22.0004

(c) Tidsskrift for Den norske legeforening 2023. Lastet ned fra tidsskriftet.no 26. april 2023. 